\title{
Rezonans idei Szkoły Lwowsko-Warszawskiej w poglądach Mariana Przełęckiego
}

\author{
Jacek Jadacki \\ (Uniwersytet Warszawski, Instytut Filozofii)
}

Nie jestem [...] wiernym spadkobiercą [...]

Szkoły Lwowsko-Warszawskiej

[Przełęcki 2007b: 201].

\section{Rezonans idei}

Termin „rezonans idei” jest metaforą, która nawiązuje do zjawiska rezonansu akustycznego. Ten ostatni polega - jak wiadomo - na tym, że fale akustyczne, wytwarzanie przez określony wibrator (tj. źródło drgań o pewnej częstotliwości, np. strunę), generują, intensyfikują lub filtrują drgania o podobnej częstotliwości w odpowiednim receptorze (np. w pudle rezonansowym). W tytule tego tekstu: Szkoła Lwowsko-Warszawska (dalej krótko: SL-W) jest wibratorem, idee szkoły to drgania o określonej częstotliwości, Marian Przełęcki to receptor, pewne jego poglądy to drgania o częstotliwości podobnej do drgań-idei SL-W - przy czym te poglądy są wytworzone, wzmocnione lub osłabione przez wspomniane idee, $\mathrm{tj}$. poglądy właściwe przedstawicielom SL-W.

Będę więc mówić o tych ideach SL-W, które Przełęcki z przedstawicielami Szkoły dzielił, ewentualnie je bądź modyfikując, tj. wzmacniając (scil. radykalizując) lub osłabiając (scil. liberalizując), bądź lepiej uzasadniając (scil. argumentując na ich rzecz). Chciałbym od razu podkreślić, że chociaż ambicją moją jest 
możliwie pełne zestawienie tego, co w twórczości Przełęckiego stanowi rezonans idei SL-W, to w żadnym razie nie można tego zestawienia uważać za pełną prezentację tej twórczości, która wykracza daleko poza ów rezonans. ${ }^{1}$

\section{Szkoła i jej przedstawiciele}

Nazwa SL-W figuruje w dwóch artykułach Przełęckiego: „Podejście do metafizyki w SL-W” [1989a] i „Antyirracjonalizm w SL-W” [1995]. W artykułach tych przedmiotem analizy jest niejako cała SL-W. Ale u Przełęckiego mamy też rezonans idei poszczególnych przedstawicieli SL-W: znajdujemy go także w pracach, których tytuł na to explicite nie wskazuje.

\section{Metodologia i filozofia}

Przełęcki pisze:

Dla filozofa SL-W ważne jest nie tylko to, jak jest, ale i to, skąd wiadomo, że tak jest. Stąd waga w jego myśleniu rozważań metodologicznych i powściągliwość w wywodach ontologicznych. Tam zaś, gdzie wysuwa się pewne koncepcje ontologiczne, nie poprzestaje się na apelowaniu do rzekomych intuicji ontologicznych, lecz usiłuje się podawać bardziej obiektywne racje [Przełęcki 1995: 103]..$^{2}$

Myślę, że diagnoza ta pozostaje prawdziwa także wtedy, gdy rozszerzy się ją $\mathrm{z}$ „wywodów ontologicznych” na całą filozofię. Dlatego niżej pokażę rezonans, jaki wywołują u Przełęckiego główne idee metodologiczne SL-W (\$\$ 4-10) oraz idee filozoficzne kilku jej przedstawicieli: Łukasiewicza, Kotarbińskiego, Czeżowskiego i Ajdukiewicza (\$\$ 11-16).

1 Tekst powstał w ramach projektu 2016/23/B/HS1/00684 „Miejsce Kazimierza Twardowskiego w kulturze polskiej i filozofii europejskiej", finansowanego przez Narodowe Centrum Nauki. Jego skrócona wersja została przedsawiona jako referat podczas konferencji Zasięg i granice metod logicznych, poświęconej pamięci Mariana Przełęckiego (1923-2013), w Warszawie, 25.06.2018.

2 Por. też: [Przełęcki 1997: 153]. 


\section{Irracjonalizm i antyirracjonalizm}

Przełęcki odróżnia dwa aspekty antyirracjonalizmu (resp. racjonalizmu) obecnego w SL-W: jeden związany jest $\mathrm{z}$ racjonalnością stawianych pytań, a drugi $\mathrm{z}$ racjonalnością uznawania głoszonych poglądów.

Pytanie jest postawione racjonalnie, gdy język, w którym zostało wyrażone, jest intersubiektywnie komunikowalny, czyli znaczeniowo określony (scil. zrozumiały), i gdy pytanie jest rozstrzygalne, czyli wiadomo „jakie są środki jego rozstrzygnięcia” [Przełęcki 1995: 98] i środki te są akceptowane przez tych, którzy mają to pytanie rozstrzygać.

Pogląd jest uznawany racjonalnie, gdy stopień jego uznawania, czyli jego prawdopodobieństwo subiektywne, jest równe stopniowi jego uzasadnienia, czyli jego prawdopodobieństwu logicznemu ze względu na określoną wiedzę (scil. stopniowi jego konfirmacji).

Według Przełęckiego najwięcej wątpliwości budzi ten drugi aspekt racjonalności, a w szczególności kwestia dopuszczalności odwoływania się w uzasadnieniu do intuicji innych niż ekstraspekcja - czyli do introspekcji, do intuicji aksjologicznej (moralnej lub estetycznej) i do intuicji (nazwę ją tak na własną odpowiedzialność) religijnej.

Introspekcję - jako jedną z podstaw uzasadniania - akceptują wszyscy główni przedstawiciele SL-W, przy czym:

Filozofowie ci akceptują tezy introspekcyjne ze względu na to, że tezy te oprócz bezpośredniego uzasadnienia introspekcyjnego dopuszczają również uzasadnienie pośrednie odwołujące się w ostatecznym rachunku do doświadczenia ekstraspekcyjnego [Przełęcki 1995: 101].

Jeśli chodzi o intuicję aksjologiczną, to większość (m.in. Twardowski, Kotarbiński, Czeżowski, Tatarkiewicz) ją także akceptowała, ale byli też tacy (np. Ossowscy), którzy jej wartość argumentacyjną odrzucali. Ci pierwsi - robili to z zastrzeżeniem, że siła uzasadniająca intuicji aksjologicznej jest jednak mniejsza niż siła uzasadniająca ekstraspekcji i introspekcji.

$\mathrm{W}$ wypadku tez religijnych - są one u tych przedstawicieli SL-W, którzy takie tezy uznają, irracjonalne $\mathrm{w}$ aspekcie uzasadnienia, gdyż ich stopień uznania - wysoki, gdyż są to dogmaty religijne - jest zdecydowanie wyższy niż stopień uzasadnienia, które pozwala co najwyżej uważać je za bardzo niepewne hipote- 
$z y .{ }^{3}$ Niektórzy przedstawiciele SL-W, uznający tezy religijne, umieszczają te tezy w sferze "prywatnej» wiary, którą oddzielają od sfery "publicznej» wiedzy.

Przełęcki dystansuje się od takiego „podwójnego myślenia”, które uważa za „Z różnych względów trudne do zaakceptowania” [Przełęcki 1995: 103].

Ogólnie - Przełęcki opowiada się za osłabieniem postulatu antyirracjonalności w sformułowaniu, w którym jest on właściwy SL-W.

Jeśli chodzi o aspekt językowy, stoi on na stanowisku, że określoność pytań (i odpowiedzi na nie) nigdy nie jest pełna - nawet w obrębie nauk empirycznych. Dlatego zamiast o dychotomii określoność-nieokreśloność adekwatniej jest mówić w ich wypadku o stopniu określoności. W konsekwencji - zamiast o dychotomii antyirracjonalność-irracjonalność lepiej byłoby może mówić o stopniu antyirracjonalności (resp. racjonalności) danego pytania/odpowiedzi. Przełęcki tak daleko jednak nie idzie. Pisze:

Jeśli nieokreśloność jakiegoś twierdzenia sprawia, iż przy pewnych dopuszczalnych interpretacjach staje się ono prawdziwe, a przy innych fałszywe, trudno racjonalnie dyskutować nad tym, czy jest tak, jak ono głosi. Aby dyskusja taka była celowa, różnice między dopuszczalnymi interpretacjami danego twierdzenia nie powinny wpływać na jego wartość prawdziwościową; wszystkie jego interpretacje winny być prawdziwe lub wszystkie fałszywe [Przełęcki 1995: 104].

\section{I dalej:}

Wśród precyzacji danego twierdzenia istnieje zawsze precyzacja taka, której stopień uzasadnienia pokrywa się ze stopniem uzasadnienia twierdzenia wyjściowego. Jest to jego interpretacja najsłabsza, odpowiadająca alternatywie wszystkich interpretacji dopuszczalnych [Przełęcki 1995: 105].

\section{Racjonalność logiczna i «stymulacyjna»}

Antyirracjonalizm postuluje racjonalność naszych poglądów, którą Przełęcki nazywa „racjonalnością logiczną” lub „racjonalnością metodologiczną” [Przełęcki 2006a: 188]. Racjonalność metodologiczną, a więc racjonalność ze względu na

3 Por. w tej sprawie: [Przełęcki 1989b]. 
dostateczne uzasadnienie - odróżnia on od racjonalności «stymulacyjnej» (którą nazywa - niezbyt szczęśliwie - „racjonalnością pragmatyczną”), właściwą dziedzinie wiary, a nie dziedzinie wiedzy. Pisze o tym tak:

W dziedzinie wykraczającej poza poznanie naukowe [...] wartością decydującą o przyjęciu danego przekonania jest nie tyle siła jego uzasadnienia, ile siła nadziei, jaką przekonanie to nam daje [Przelęcki 2006a: 189].

W SL-W najdobitniej o takiej racjonalności stymulacyjnej - do której i ja skądinąd czuję się w prawie odwoływać - mówił Łukasiewicz, cytowany za mną przez Przełęckiego:

Wierzymy, że świat jest urządzony rozumnie i celowo, bo czerpiemy stąd pokrzepienie na dzień dzisiejszy, a nadzieję i ufność na niepewne dni przyszłe [Przełęcki 2006a: 188].

\section{Sfera analizy}

Przełęcki w następujący sposób określa swoistość SL-W, a dokładniej - stanowiącej jej jądro Polskiej Szkoły Logicznej:

[Jej] charakter szczególny [...] najtrafniej można określić słowem „analityczny". Główny wysiłek jest tu bowiem skierowany na wstępną analizę znaczeniową wchodzących w grę terminów: analizę mającą na celu uwyraźnienie ich znaczeń i stosującą dla osiągnięcia tego celu metody logiczne. Toteż najczęstszym rezultatem takich wysiłków jest nie tyle rozwiązanie danego problemu, ile raczej postawienie go w sposób bardziej jednoznaczny i precyzyjny, a tym samym wolny od słownych nieporozumień. Trudno przecenić znaczenie takich wyników tam, gdzie w grę wchodzą problemy notorycznie niejasne i trudno uchwytne, a takie właśnie bywają tu najczęściej przedmiotem rozważań [Przełęcki 1971: 116].

Jaki jest zasięg takich analiz? Trzeba tu odróżnić analizę pojęć od analizy wypowiedzi - w tym: pojęć i wypowiedzi filozoficznych. W tym drugim wypadku rodzi się pytanie: Czy każda wypowiedź filozoficzna - nawet mająca postać 
zupełnej fantazji lub fantasmagorii intelektualnej - nadaje się do tego, aby być przedmiotem analizy? A jeśli tak, to czy warto takie wypowiedzi analizować?

Odpowiedź Przełęckiego na pierwsze pytanie jest negatywna: są wypowiedzi, np. dotyczące ważnych spraw światopoglądowych, które nie nadają się do analizy - i muszą pozostać nieinterpretowalnymi literalnie metaforami.

W SL-W na drugie pytanie nie odpowiadano na ogół w sposób stanowczy, chociaż jedni byli w tej sprawie mniej, inni zaś bardziej surowi. Do tych pierwszych należała np. Kotarbińska, którą Przełęcki uważał za główną swoją mentorkę. Sam Przełęcki skłaniał się natomiast do tych drugich, pisząc o Kotarbińskiej, że niekiedy „czyniła zbyt wielki zaszczyt [...] niejasnym i nieodpowiedzialnym wywodom” niektórych filozofów, poddając je „sumiennej analizie” [Przełęcki 1971: 117].

\section{Rekonstrukcjonizm i deskrypcjonizm}

Szczególnym rodzajem analizy jest analiza - lub może należałoby powiedzieć: rekonstrukcja - formalna (scil. logiczna). Nie jest łatwo powiedzieć, na czym ona dokładnie polega. ${ }^{4}$ Rozpocznę od ogólnikowych sformułowań Przełęckiego odnoszących się do metodologii formalnej, którą sam z powodzeniem uprawiał:

Jej przedstawiciele poddają badane teorie empiryczne radykalnej rekonstrukcji logicznej na wzór teorii matematycznych. Umożliwia im to stosowanie podobnych, jak w matematyce, metod formalnych, a w konsekwencji wysoką precyzję sformułowań i niezawodność wywodów. Istnieją problemy, które na tej tylko drodze mogą być sformułowane w sposób rozstrzygalny; istnieją takie, które na tej tylko drodze mogą być w ogóle postawione. Osiąga się to za cenę idealizacji, a więc i pewnej deformacji badanych teorii empirycznych [Przełęcki 1971: 124].

Mówiąc mniej ogólnikowo - i zarazem bardziej ogólnie: rekonstrukcja (resp. interpretacja) logiczna jakiegoś systemu teoretycznego polega na eksplikacji, a więc „przekładzie tez tego systemu na język pewnej zaksjomatyzowanej i sfor-

4 Sprawie tej poświęciłem tekst „Semi-formal analysis of the opposition formality-informality in the spirit of the Lvov-Warsaw School", przewidziany do wygłoszenia podczas sympozjum Formal and informal methods in philosophy (Warszawa, 25-27.06.2018). 
malizowanej teorii”, ${ }^{5}$ mającej zagwarantowaną „określoność pojęcia wynikania i innych pochodnych wobec niego pojęć logicznych” [Przełęcki 1997: 149] - a więc ujawnienie struktury logicznej interpretowanego systemu teoretycznego. Wymaga to, rzecz jasna, uprzedniego dokonania intuicyjnej interpretacji systemu wyjściowego i wskazania pewnej zamierzonej pozaformalnej interpretacji (scil. treści) teorii - takiej, że na jej język zostaje przełożony system wyjściowy; interpretacja taka podana jest zazwyczaj w tzw. komentarzu słownym do tej teorii, a ów komentarz sformułowany być musi w języku naturalnym. W ten dopiero sposób, według Przełęckiego, może zostać określona dziedzina owej teorii; dziedzina ta może i musi być określona, gdyż bez tego pytanie o prawdziwość tez rozpatrywanej teorii pozostanie zawieszona w próżni. ${ }^{6}$

Dlatego Przełęcki daleki był od przeceniania wartości rekonstrukcji logicznej np. w filozofii. Pisał w tej sprawie:

Sceptycznie [...] zapatruję się na rolę rachunków logicznych w rozważaniach filozoficznych. Precyzacja, którą wnoszą do tych rozważań dotyczy tylko ich strony formalnej, a nie treściowej. Tej ostatniej żaden rachunek logiczny uchwycić nie jest w stanie [Przełęcki 1994: 192]. ${ }^{7}$

Sprawa stosowalności metod formalnych w dyscyplinach innych niż matematyczne jest przedmiotem sporu rekonstrukcjonistów z deskrypcjonistami. Ci ostatni uważają, że rekonstrukcja prowadzi do niedopuszczalnego zniekształcenia przedmiotu analizy. Ma być tak dlatego, że:

Aparat formalno-logiczny może być stosowany tylko do języków sztucznych, o dokładnie ustalonych regułach konstrukcji. Stosowanie go do języka naturalnego, dla którego reguły takie nie są wyraźnie sformułowane, jest nadużyciem, deformującym język taki w sposób istotny [Przełęcki 1971: 123].

Warto zauważyć, że Przełęcki większą rolę przypisuje tutaj formalizacji - nie zaś aksjomatyzacji. Jak pisze: „Podczas gdy aksjomatyzacja ustala własności logiczne pojęć, formalizacja określa ich status logiczny. Pozwala odpowiedzieć na pytanie, czy dane pojęcie odnosi się, dajmy na to, do pewnej własności czy funkcji, a jeśli do funkcji, to iluargumentowej, i co stanowi jej argumenty i wartości" [Przełęcki 1997: 152].

6 Nawiasem mówiąc, osobiście uważam, że do tego określenia, w pewnych przynajmniej wypadkach, można się posłużyć innym, uprzednio już dostatecznie sprecyzowanym językiem, a ostatecznie - ostensją. Zresztą i Przełęcki niekiedy stawia sprawę inaczej: rolę języka naturalnego może spełniać w pewnych wypadkach język „terminów obserwacyjnych” [Przełęcki 2003: 179].

7 Nawiasem mówiąc - nie podzielam poglądu Przełęckiego w tej sprawie. 
Przełęcki - idąc w tym za Kotarbińską - zajmuje stanowisko „umiarkowane”. Formalizacja deformuje język naturalny - i w tym deskrypcjoniści mają rację. Jednakże - wbrew nim - nie jest to deformacja na tyle istotna, że uniemożliwia „powrót do rzeczywistości”. Według Przełęckiego:

Istnieje możliwość [...] przeniesienia z pewnym przybliżeniem na sytuację rzeczywistą rozwiązania otrzymanego dla sytuacji idealnej. [Tyle, że] ta procedura konkretyzacji wymyka się już metodom czysto formalnym. Toteż [...] na tej drodze badawczej nie likwidujemy bynajmniej konieczności dociekań nieformalnych; koncentrujemy je tylko na określonym etapie badań, uwalniając od nich inne. Metodologia formalna nie może zastąpić metodologii nieformalnej - może być tylko jej uzupełnieniem [Przełęcki 1971: 124].

Nawiasem mówiąc - jest to stanowisko bliskie stanowisku deklarowanemu w SL-W przez Łukasiewicza; natomiast założyciel Szkoły skłaniał się raczej ku deskryptywizmowi. ${ }^{8}$

\section{Analityczność i definicje}

Z dwóch rodzajów zdań analitycznych: tych, które są prawami logiki (czyli podstawieniami tautologii logicznych), i tych, które takimi prawami nie są (jak np. zdanie „Żaden kawaler nie jest żonaty”) - teoretycznie ciekawsze są te drugie. Ajdukiewicz traktował je jako konsekwencje definicji (projektujących) lub ogólniej: jako konsekwencje postulatów znaczeniowych danego języka. ${ }^{9}$

Przełęcki uważał propozycję Ajdukiewicza za „najdojrzalszą próbę” ujęcia tego zagadnienia [Przełęcki 1963: 256]. Był przy tym zdania, że:

Niewątpliwie chwyta ona jedno ze znaczeń, jakie wiążemy z pojęciem zdania analitycznego. Jednocześnie [...] koncepcja ta pociąga konsekwencje niezgodne $\mathrm{z}$ innymi intuicjami dotyczącymi zdań analitycznych. Konsekwencje te wydają się świadczyć o tym, że jest to koncepcja zbyt szeroka, zaliczająca do

\footnotetext{
8 Zob. tekst mojego referatu „Wkład Kazimierza Twardowskiego w rozwój logiki w Polsce”, wygłoszonego podczas sympozjum Szkoła Lwowsko-Warszawska - historia $i$ kontynuacja tradycji (Wrocław, 19-20.04.2018).

9 Por.: [Przełęcki 1988: 58 i nn.].
} 
zdań analitycznych pewne twierdzenia, których byśmy tam skądinąd zaliczyć nie chcieli [Przełęcki 1963: 257].

Rozważmy dla przykładu projektującą definicję cząstkową terminu 'Q' o postaci (z pominięciem generalizatora wiążącego zmienną indywiduową ' $x$ '):

(1) $(P x \rightarrow Q x) \wedge(R x \rightarrow \sim Q x)$.

Konsekwencją definicji (1) jest m.in. teza:

(2) $P x \rightarrow \sim R x$.

Tezę (2) - jako konsekwencję definicji (1) - należałoby uznać za zdanie analityczne; tymczasem ma ona „charakter syntetyczny” [Przełęcki 1963: 259] - i jako taka może okazać się tezą fałszywą. Przełęcki proponuje, aby usunąć ten paradoks przez wyodrębnienie w definicjach cząstkowych dwóch składników: analitycznego i syntetycznego. Dla definicji typu (1) składnikiem syntetycznym byłaby teza (2), a składnikiem analitycznym - teza:

(3) $[(P x \wedge \sim R x) \rightarrow Q x] \wedge[(R x \wedge \sim P x) \rightarrow \sim Q x]$.

Przy takim ujęciu wszystkie konsekwencje składnika (2) byłyby zdaniami syntetycznymi, a wszystkie konsekwencje składnika (3) - zdaniami analitycznymi.

\section{Radykalny konwencjonalizm}

Za pewną wersją radykalnego konwencjonalizmu w obrębie SL-W w swoim czasie opowiedział się Ajdukiewicz. Zgodnie z tą wersją - wszelkie twierdzenia naukowe mają „charakter konwencjonalny”, umowny: o ich przyjęciu lub odrzuceniu ma rozstrzygać „nie doświadczenie, lecz co najwyżej wzgląd na - tak czy inaczej rozumianą - wygodę" [Przełęcki 1957: 51].

Przełęcki - może warto to odnotować: w połowie lat pięćdziesiątych - uznawszy, że „paradoksalność radykalnych doktryn konwencjonalistycznych jest oczywista" [Przełęcki 1957: 52], przedstawił racje przemawiające na rzecz doktryn konwencjonalistycznych zliberalizowanych, „ostrożniejszych”, które za konwencjonalne uznają „tylko pewne wybrane twierdzenia” naukowe, np. prawa fizyki, 
powołując się na „wyniki analizy twierdzeń i metod nauk szczegółowych” [ibdem].

Interesujące Przełęckiego doktryny konwencjonalistyczne obejmują m.in. dwie tezy:

(1) Twierdzenia, mające pozór praw przyrodniczych, są w istocie „definicjami podstawowych pojęć przyrodniczych lub konsekwencjami takich definicji” [Przełęcki 1957: 53].

(2) „Definicje podstawowych pojęć” przyrodniczych mają „charakter arbitralny" [ibidem].

Zakłada się przy tym, że tezy (1) i (2) są skwantyfikowane za pomocą generalizatorów, tj. mówi się w nich o wszYsTкіCH twierdzeniach (kauzalnych i koegzystencjalnych) i wszYsткісн definicjach. Osłabienie konwencjonalizmu przez Przełęckiego polegało na zamianie kwantyfikatora „wszystkie” na kwantyfikator „tylko niektóre” oraz na wskazaniu, że zarówno twierdzenia, o których mowa w (1), a które nazywa się czasem „zasadami”, jak i definicje, o których mowa w (2), mają empiryczną (scil. doświadczalną) genezę. Konkluzja Przełęckiego brzmiała:

\begin{abstract}
Zarówno definicje [...], jak i pewne [...] zasady fizykalne - to środki służące do budowy aparatu pojęciowego nauk przyrodniczych. Jako twierdzenia analityczne nie podlegają one kontroli doświadczenia. Doświadczenie nie decyduje o ich prawdziwości czy fałszywości. [...] Doświadczenie decyduje jednak o tym, czy nadają się one do realizacji zadań, jakie stoją przed naukami przyrodniczymi. Nie chodzi tu o ich mniejszą czy większą dogodność. Przyjmujemy taką a nie inną definicję czy postulat znaczeniowy nie dlatego, że przyjęcie innej spowodowałoby wykonanie owego zadania w sposób mniej dogodny, lecz dlatego, że uniemożliwiałoby ono w ogóle jego realizację. W tej sytuacji nie można twierdzeń tych nazywać „,arbitralnymi umowami” [Przełęcki 1957: 67-68].
\end{abstract}

\title{
Semantyka i metafizyka
}

Przełęcki był - według mego rozeznania - jednym z nielicznych logików i filozofów naprawdę rozumiejących, na czym polega koncepcja prawdy, która pojawiła się w okresie międzywojennym w Warszawskiej Szkole Logicznej i której znaną 
na świecie postać nadał Tarski. Nie będę ukrywał, że sam zrozumiałem, o co w niej chodzi, pod wpływem długich rozmów podczas moich wizyt w Otwocku, gdzie Przełęcki mieszkał w ostatnich latach swego życia.

Oto dwuzdaniowa kwintesencja tej koncepcji prawdy:

Semantyczna definicja zdania prawdziwego sformułowana w sposób ścisły przybiera [...] postać [...] definicji indukcyjnej. Jej warunek wyjściowy określa prawdziwość zdań prostych («atomowych»), a warunek indukcyjny prawdziwość zdań złożonych [Przełęcki 1973: 368].

Dość powszechnie uważa się, że koncepcja ta jest - jak to się mówi - „filozoficznie neutralna”. Tymczasem według Przełęckiego:

Sposób interpretacji owego warunku indukcyjnego może być [...] przedmiotem dyskusji ujawniającej różnice stanowisk nieobojętne pod względem filozoficznym. Konsekwencje filozoficzne [...] związane są jednak przede wszystkim ze sposobem interpretacji warunku wyjściowego [ibdem].

Pierwotne sformułowanie warunku wstępnego definicji przybiera postać:

(1) Zdanie ' $p$ ' jest prawdziwe, gdy $p .^{10}$

Przełęcki pierwotnemu sformułowaniu tego warunku nadaje postać teorio-modelową:

(2) Zdanie ' $p$ ' jest prawdziwe, gdy $p$, w interpretacji wyznaczonej przez zamierzony model - lub klasę takich modeli - języka, do którego należy zdanie ' $p$ '.

Jeśli zdaniem ' $p$ ' byłoby zdanie ' $a$ jest $P$ ', a modelem dla jego języka byłaby dziedzina teorii mnogości, to formuła (2) przybrałaby postać:

(3) Zdanie ' $a$ jest $P$ ' jest prawdziwe, gdy $a$ należy do zbioru będącego denotacją predykatu ' $P$ '.

Otóż jeżeli w zdaniu 'p’ występuje co najmniej jeden termin nieostry (a takie terminy występują często w zdaniach należących do języków empirycznych oraz w zdaniach oceniających), to nie da się wskazać takiego zamierzonego modelu

10 Często warunek (1) traktuje się jako „kryterium adekwatności semantycznej definicji prawdy” [Przełęcki 1977: 382]. Nie uważam takiego ujęcia za szczęśliwe.

11 Zwracam uwagę na różnicę między definiensem - członem występującym po łączniku „gdy” definicji (1) i definicji (2). 
języka, do którego należy zdanie ' $p$ ', ${ }^{12}$ że ten model wyznaczałby dokładnie jedną interpretację owego zdania. Tym samym niektóre (ale: TYLKo niektóre!) zdania empiryczne i oceniające nie byłyby - na gruncie warunku wstępnego ze sformułowania (2) - ani prawdziwe, ani fałszywe, a więc byłyby pozbawione wartości logicznej. W rezultacie - koncepcja prawdy, zdefiniowana przy pomocy warunku (2), pociągałaby za sobą ograniczenie ważności metalogicznej zasady wyłączonego środka, co skądinąd jest po myśli Przełęckiego.

I to jest właśnie jedna z metafizycznych konsekwencji tej koncepcji prawdy.

\section{Indeterminizm ontologiczny}

Niewielu przedstawicieli SL-W było indeterministami, ale był wśród nich nie byle kto, bo sam Łukasiewicz. Przełęcki odróżnia w doktrynie ontologicznej Łukasiewicza część negatywną i część pozytywną.

Część negatywna - to krytyka pewnej argumentacji przemawiającej za determinizmem. Według Łukasiewicza - determinizm głosi, że:

(1) Jeżeli jakieś zdarzenie zachodzi w określonej chwili $t$, to w każdej chwili wcześniejszej niż chwila $t$ zachodzi jakaś przyczyna owego zdarzenia: bezpośrednia lub pośrednia.

Determiniści wyprowadzają pogląd (1) z tego, że:

(2) Każde zdarzenie ma nieskończony ciąg przyczyn.

Otóż to wyprowadzenie jest - jak pokazuje Łukasiewicz - bezpodstawne, gdyż nieskończony ciąg przyczyn może być ograniczony w czasie. I tę negatywną część doktryny Łukasiewicza Przełęcki aprobuje.

Inaczej jest z częścią pozytywną tej doktryny - tj. argumentacją na rzecz indeterminizmu. Łukasiewicz przez „indeterminizm” rozumie pogląd, że:

(3) Są zdarzenie przyszłe, powiedzmy to, że $p$, które nie są przesądzone w określonej chwili $t$ - a więc w chwili $t$ nie zachodzi ani przyczyna tego, że $p$, ani przyczyna tego, że nie-p.

12 Co najmniej wtedy - gdy jest to (meta)język teorio-mnogościowy. Por.: [Przełęcki 1987: 393]. 
Tak rozumiany indeterminizm jest możliwy, a więc da się pogodzić z poglądem (2). Sam Łukasiewicz podkreśla, że nie przesądza to prawdziwości tezy indeterministycznej.

Komentarz Przełęckiego jest taki:

Argumentacja za indeterminizmem [...] byłaby [...] o wiele wiarygodniejsza, gdyby miała służyć jako argumentacja na rzecz indeterminizmu wziętego jako pewien pogląd epistemologiczny, tj. jako teza dotycząca naszej wiedzy [Przełęcki 1989a: 92-93].

Prawdę mówiąc, nie jest jasne, jaki kształt, zdaniem Przełęckiego, miałaby przyjąć wtedy teza (3). Zaryzykuję następujący:

(4) Są zdarzenie przyszłe, o których w określonej chwili $t$ nie wiadomo, czy zajdą one, czy też nie zajdą w jakiejś chwili późniejszej niż chwila $t$.

\section{Modalność ontyczna i aletyczna}

$\mathrm{Na}$ tezie indeterminizmu opiera się Łukasiewiczowska koncepcja możliwości. Przełęcki relacjonuje tę koncepcję tak:

(1) Stany rzeczy, których zajście nie jest jednoznacznie wyznaczone przez ogół stanów rzeczy wcześniejszych - to możliwe stany rzeczy.

(2) Spośród przyszłych stanów rzeczy - niektóre są możliwymi stanami rzeczy.

(3) Zdania opisujące możliwe stany rzeczy - to zdania możliwe.

(4) Zdania możliwe mają nieokreśloną wartość logiczną, tj. nie są ani prawdziwe, ani fałszywe.

Ocena Przełęckiego tej koncepcji jest następująca:

Daleka jest [ona] od jasności - zwłaszcza w swej warstwie interpretacyjnej. Nie tylko dlatego, że opiera się na wysoce wątpliwym założeniu, ale i dlatego, że posługuje się pojęciami nie dość jasnymi i ścisłymi. Jej precyzacja wymagałaby wprowadzenia wyraźnej relatywizacji do czasu; posługiwania się, w szczególności, zrelatywizowanym do czasu pojęciem prawdziwości: po- 
jęciem zdania prawdziwego w chwili $t$. Muszę się przyznać, że sens takiego zwrotu pozostaje dla mnie dość zagadkowy [Przełęcki 1974: 322].

Pomińmy sprawę zagadkowości zwrotu „prawdziwy w określonej chwili”. Otóż zarzut niejasności i nieścisłości daje się stosunkowo łatwo uchylić przez precyzację tez (1)-(4).

Zgódźmy się (dla uproszczenia), że dany stan rzeczy (ewentualnie ciąg stanów rzeczy) jednoznacznie określa pewien inny - późniejszy - stan rzeczy, gdy ten pierwszy jest przyczyną tego drugiego. Wtedy za precyzację tez (1)-(4) można uznać następujące formuły:

(5) Zdanie $Z$ jest możliwe w chwili $t \leftrightarrow(\sim Z$ jest prawdziwe w chwili $t \wedge \sim Z$ jest fałszywe w chwili $t$ ).

(6) (W chwili $t_{\mathrm{k}}$ zdanie $Z$ jest możliwe $\wedge$ zdanie $Z$ stwierdza, że $p$ ) $\rightarrow \sim \vee t$ (chwila $t$ jest tożsama lub wcześniejsza względem chwili $t_{\mathrm{k}} \wedge \mathrm{w}$ chwili $t$ zaszła przyczyna tego, że $p$ ).

\section{Reizm ontologiczny i semantyczny}

Reizm ontologiczny Kotarbińskiego głosi, że:

(1) Każdy przedmiot jest rzeczą.

Jako uzasadnienie tezy (1) Kotarbiński podaje tezę reizmu semantycznego, głoszącą (w mojej parafrazie) że:

(2) Jeżeli jakieś zdanie dotyczy przedmiotów innych niż rzeczy i jest prawdziwe, to zdanie to jest redukowalne do pewnego zdania dotyczącego rzeczy.

Przy tym, jak zaznacza Przełęcki:

(3) Zdanie $Z_{1}$ jest redukowalne do zdania $Z_{2}$, gdy właściwy sens zdania $Z_{1}$ jest niedosłowny i identyczny $z$ dosłownym sensem zdania $Z_{2}$.

W związku z tezą reizmu semantycznego Przełęcki odnotowuje:

Jej uniwersalności ma przeczyć konflikt z matematyką, której wypowiedzi okazują się nieprzekładalne na język rzeczy. Otóż zauważyć warto, że z fak- 
tu tego można równie dobrze wysnuć wniosek odmienny - niepodważający ogólności programu reistycznego, lecz kwestionujący literalną sensowność wypowiedzi matematycznych. Nie jest bynajmniej rzeczą oczywistą, że są to zdania sensowne semantycznie - prawdziwe lub fałszywe twierdzenia o rzeczywistości. Z ich funkcji poznawczych można, jak sądzę, zdać sprawę nie przypisując im sensowności innej niż syntaktyczna, a więc czysto formalna [Przełęcki 1976: 110].

Natomiast jeśli chodzi o status tezy (2) jako tezy uzasadniającej tezę reizmu ontologicznego, to Przełęcki podkreśla, że wchodzić tu może w grę jedynie uzasadnienie redukcyjne, gdyż to teza (2) wynika $z$ tezy (1) - a nie na odwrót. W ten sposób teza (1) jest tylko hipotezą wyjaśniającą dla tezy (2). Według Przełęckiego - podobnie oceniał status reizmu ontologicznego sam Kotarbiński.

Przełęcki zarazem wzmacnia uzasadnienie Kotarbińskiego, dodając do niego zasadę zwaną „brzytwą Ockhama”:

Skoro, według semantycznej tezy reizmu, nasza wiedza jest wyrażalna bez przyjmowania istnienia przedmiotów innych niż rzeczy, takie założenie jest, w pewnym sensie, niepotrzebne; a więc nie powinniśmy przyjmować istnienia przedmiotów innych niż rzeczy - w zgodzie z postulatem: entia non sunt multiplicanda praeter necessitatem [Przełęcki 1989a: 94]. ${ }^{13}$

Jak zauważa Przełęcki - i jest to bardzo istotne spostrzeżenie - formuła (2) mówi o redukowalności do zdań reistycznych nie wszystkich, lecz prawdziwych zdań niereistycznych. Bez tego uzupełnienia - brzytwa Ockhama nie dałaby się zastosować we wskazany sposób w argumentacji na rzecz reizmu ontologicznego.

\section{Realizm ontologiczny}

Tezę realizmu ontologicznego w ujęciu Ajdukiewicza, który się za nią opowiadał, wolno zrekonstruować następująco:

(1) Nie jest tak, że: zachodzi to, że $p$, gdy ‘ $p$ ’ jest tezą języka nauki.

W konsekwencji bywa tak, że zachodzi pewien stan rzeczy, ale nie jest on stwierdzany przez żadną tezę naukową.

13 Zob. w tej sprawie także [Przełęcki 1984]. 
Argumentacja podana przez Ajdukiewicza na rzecz tezy (1) wygląda, według Przełęckiego, tak. Załóżmy, że prawdziwa jest teza idealizmu ontologicznego, a więc negacja tezy (1) - czyli teza:

(2) Zachodzi to, że $p$, gdy 'p' jest tezą języka nauki.

Ajdukiewicz podaje epistemologiczną parafrazę (2) w postaci:

(3) Zdanie ' $p$ ' jest prawdziwe, gdy ' $p$ ' jest tezą języka nauki.

Następnie wykazuje fałszywość tezy (3). Jak to streszcza Przełęcki:

Zbiór prawd nie może być utożsamiony ze zbiorem twierdzeń, ponieważ, zgodnie z metalogiczną zasadą wyłączonego środka, zbiór prawd jest zupełny, podczas gdy, zgodnie z twierdzeniem Gödla, zbiór twierdzeń języka nauki [...] jest niezupełny [Przełęcki 1989a: 95].

Skoro zaś fałszywa jest teza (2), to prawdziwa jest jego negacja $\mathrm{w}$ postaci tezy (1).

Przełęcki kwestionuje uniwersalność metalogicznej zasady wyłączonego środka; według niego nie stosuje się ona do języków nieostrych - a takim jest język nauki. ${ }^{14}$ Akceptuje natomiast uniwersalny walor logicznej zasady wyłączonego środka, co pozwala mu odrzucić tezę (2).

\section{Realizm praktyczny}

Sztandarowym postulatem etycznym Kotarbińskiego był realizm praktyczny. Przełęcki gotów jest się za tym postulatem opowiedzieć „tylko pod warunkiem pewnych jego ograniczeń" [Przełęcki 2006c: 33].

Jak wygląda ten postulat w sformułowaniu Kotarbińskiego - i jakie ograniczenie chciałby nałożyć na ten postulat Przełęcki?

(1) Rozumnie działa ten, kto z dwóch dostępnych mu działań wybiera działanie ważniejsze.

(2) $\mathrm{Z}$ dwóch działań ważniejsze jest to, które „zapobiega większemu złu lub większe zło uchyla" [Przełęcki 2006c: 33].

(3) Największym złem jest cierpienie ludzkie.

$14 \quad$ Zob. w tej sprawie [Przełęcki 1982]. 
Przełęcki pisze o tym realizmie praktycznym tak:

Kotarbińskiego „etyka walki z cierpieniem” pozostaje nadal trafnym wyrazem moich najgłębszych poczuć moralnych. [...] Etyka ta wymaga [jednak] innego ujęcia pojęciowego [Przełęcki 2006c: 34].

Na podstawie - nie mogę tego nie powiedzieć - dość mglistego przedstawienia przez Przełęckiego tego „innego ujęcia” mamy prawo powiedzieć, że wyglądałoby ono chyba tak:

(4) Ludzie dążą do szczęścia, tj. do tego, co daje im zadowolenie.

(5) Różne rzeczy - w tym także „niepraktyczne” [Przełęcki 1976: 110] - dają różnym ludziom to zadowolenie: twórczość, miłość, cnota (scil. doskonałość moralna).

(6) Żadna z tych rzeczy - jako taka - nie podlega ocenie moralnej, a w szczególności nie jest doskonalsza (resp. właściwsza) moralnie niż pozostałe.

(7) Ocenie moralnej podlegają natomiast DZIAŁANIA, które prowadzą do osiągnięcia szczęścia.

(8) Właściwie moralnie działa ten, kto z dwóch dostępnych mu działań wybiera działanie ważniejsze.

(9) Z dwóch działań ważniejsze jest to, które „zapobiega większemu złu lub większe zło uchyla".

(10) Największym złem jest cierpienie ludzkie.

Jeśli formuły (4)-(10) są uprawioną interpretacją ujęcia Przełęckiego, to wprowadza ono do realizmu praktycznego, wyrażonego w formułach (1)-(3), następujące modyfikacje:

(a) dodaje formuły (4)-(7), z których dwie pierwsze są formułami opisowymi, a dwie pozostałe - są ocenami moralnymi;

(b) modyfikuje formułę (1), nadając jej postać formuły (7), w której miejsce „działania rozumnego” zajęte zostaje przez „działanie właściwe moralnie”.

W konsekwencji - w kategoriach moralnych ocenia się nie (jak u Kotarbińskiego) cele, które ludzie sobie stawiają, lecz działania, które miałyby do osiągnięcia tych celów prowadzić - nakładając na te działania kaganiec moralności. 


\section{Eternalizm etyczny}

Rozważmy następującą sekwencję tez:

(1) Jeżeli dany czyn był czynem wartościowym moralnie, to pozostanie taki na zawsze.

(2) Życie danego człowieka ma sens aksjologiczny (scil. jest aksjologicznie sensowne), jeżeli czyny tego człowieka są wartościowe moralnie.

\section{Zatem:}

(3) Jeżeli życie danego człowieka miało sens aksjologiczny, to pozostanie sensowne aksjologicznie na zawsze.

W braku przyjętego powszechnie określenia - nazwę tezę (3), ewentualnie wraz z jej racjami (1) i (2) - „eternalizmem etycznym”. Eternalizm taki wyznawał w SL-W Czeżowski. Przełęcki cytuje z aprobatą następującą jego wypowiedź:

Życie, które minęło, nie zapada w nicość, lecz pozostaje zawsze życiem, choć przeszłym, i zachowuje przysługującą mu wartość [Przełęcki 2006b: 44].

Zwolennik postulatów metodologicznych SL-W czułby się w obowiązku precyzacji tak ujętego eternalizmu. W szczególności chodziłoby o komentarze do tezy (2). Chodzi o to, że teza (2) podaje tylko wystarczający warunek sensowności życia - i o to, że czyny wypełniające życie ludzkie, o których mowa w tezie (2), miewają różną wartość (negatywną lub pozytywną, obie w różnych stopniach), więc ocena sensowności całego życia musiałaby być poprzedzona niełatwym rachunkiem dóbr. Przełęcki takich komentarzy nie robi. Uzupełnia tylko sekwencję (1)-(3) dwiema tezami o sensowności resp. absurdalności śmierci:

(4) Śmierć człowieka byłaby absurdalna, gdyby niweczyła sens jego życia.

Ale, zgodnie z tezą (3), sens życia ludzkiego - jeśli to życie ma ów sens - jest niezniszczalny. Zatem:

(5) Śmierć człowieka nie jest absurdalna, gdyż nie niweczy sensu, który ewentualnie miało jego życie.

Dodajmy sformułowanie jeszcze dobitniejsze: 
Tego, co było, nic nie jest w stanie unicestwić. Co więcej, przeszłość jest nie tylko równie realna, ale i równie ważna jak teraźniejszość [Przełęcki 1992: 137].

\section{«Filtrowanie» idei}

Dokonany przegląd rezonansu, który wywołały u Przełęckiego idee zrodzone w SL-W (a dokładniej: sformułowane przez Twardowskiego i przedstawicieli dwóch następnych pokoleń Szkoły), upoważnia do stwierdzenia, że rezonans ten polegał najczęściej na «filtrowaniu», „rozluźnianiu” [Przełęcki 1991: 113], osłabianiu tych idei.

Zaryzykowałbym ogólniejszą hipotezę historyczną: rezonans w sferze idei filozoficznych (a może nawet szerzej: humanistycznych) polega prawie zawsze na ich osłabieniu. Hipoteza ma dwa założenia.

Pierwsze założenie Przełęcki sformułował następująco:

Powinniśmy [...] oddzielać wyraźnie dwie sprawy: to, co w dorobku danego filozofa jest najbardziej twórcze i oryginalne, i to, co z takich czy innych względów wydaje nam się najbliższe [Przełęcki 1991: 113].

Zgodnie z drugim założeniem, które skądinąd implicite przyjmuje także Przełęcki, oryginalne idee filozoficzne - oryginalne, tj. takie, które są w ogóle zdolne wywołać jakikolwiek rezonans - są ideami radykalnymi, „śmiałymi” [Przełęcki 2007c: 133], „prowokującymi” [Przełęcki 1991: 112], «nieostrożnymi»: są (jak mawiał Ingarden) „przedwczesnymi rozstrzygnięciami”. Idee, które mają swoją historię, nie są ideami «ostrożnymi», które by w ciągu tej historii ulegały radykalizacji, «intensyfikacji». Trudno byłoby w każdym razie takie idee znaleźć.

Jest więc chyba tak, że myśliciele ostrożni nie mają szans na to, by ich twórczość wywołała rezonans.

\section{Wykaz przytaczanych prac Mariana Przełęckiego}

1957 Prawa a definicje. Zob.: [Przełęcki 2007: 51-68].

1963 O pojęciu zdania analitycznego. Zob.: [Przełęcki 1993: 255-277]. 
1969 Logika teorii empirycznych. Warszawa 1988: PWN.

1971 O twórczości naukowej Janiny Kotarbińskiej. Zob.: [Przełęcki 2007a: 116124].

1973 O pewnych filozoficznych konsekwencjach semantycznej definicji prawdy. Zob.: [Przełęcki 1993: 367-378].

1974 O świecie rzeczywistym i światach możliwych. Zob.: [Przełęcki 1993: 313323].

1976 W dziewięćdziesiątą rocznicę urodzin Tadeusza Kotarbińskiego. Zob.: [Przełęcki 2007a: 110-111].

1977 Pojęcie prawdy w językach nauk empirycznych. Zob.: [Przełęcki 1993: 379-387].

1982 Zasada wyłączonego środka a zagadnienie idealizmu. Zob.: [Przełęcki 1993: 335-356].

1984 Argumentacja reisty. Zob.: [Przełęcki 1993: 347-364].

1987 Prawda. Zob.: [Przełęcki 1993: 389-399].

1989a Podejście do metafizyki w Szkole Lwowsko-Warszawskiej. Zob.: [Przełęcki 2007a: 89-97].

1989b Problem racjonalności wierzeń religijnych. Zob.: [Przełęcki 2002: 88-97].

1991 O przesłaniach filozofii Tadeusza Kotarbińskiego. Zob.: [Przełęcki 2007a: 112-113].

1992 Wspomnienie o Klemensie Szaniawskim. Zob.: [Przełęcki 2007a: 136137].

1993 Studia $z$ metodologii formalnej. Warszawa: Filozofia Nauki (numer specjalny).

1994 Filozofia wartości w ujęciu Bogusława Wolniewicza. Zob.: [Przełęcki 2007a: 190-192].

1995 Antyirracjonalizm w Szkole Lwowsko-Warszawskiej. Zob.: [Przełęcki 2007a: 98-105].

1997 Hermeneutyka logiczna w ujęciu Bogusława Wolniewicza. Zob.: [Przełęcki 2007a: 148-154].

2002 O rozumności i dobroci. Warszawa: Wydawnictwo Naukowe Semper.

2003 Religijny sens istnienia w ujęcia Andrzeja Grzegorczyka. Zob.: [Przełęcki 2007a: 175-184].

2006a Racjonalność wiary religijnej w ujęciu Jacka Jadackiego. Zob.: [Przełęcki 2007a: 184-189]. 
2006b Uwagi o sensie życia i śmierci. Zob.: [Przełęcki 2007a: 42-48].

2006c W sprawie realizmu praktycznego. Zob.: [Przełęcki 2007a: 33-37].

2007a Horyzonty metafizyki. Warszawa: Wydawnictwo Naukowe Semper.

2007b Rozmowa [Anny Brożek] z Profesorem Marianem Przełęckim. Zob.:

[Przełęcki 2007a: 198-203].

2007c Wspomnienie o Kazimierzu Ajdukiewiczu. Zob.: [Przełęcki 2007a: $132-c]$.

\section{Streszczenie}

W artykule omawiam idee, które dzielił Marian Przełęcki z przedstawicielami Szkoły Lwowsko-Warszawskiej - bądź je modyfikując, bądź lepiej argumentując na ich rzecz. Są to m.in.: antyirracjonalizm (umiarkowany), racjonalizm stymulacyjny (w stosunku do wiary), rekonstrukcjonizm logiczny (powściągliwy), konwencjonalizm (zliberalizowany), indeterminizm ontologiczny (w części negatywnej), uznanie reizmu ontologicznego za hipotezę wyjaśniającą względem reizmu semantycznego, dyrektywa realizmu praktycznego (wobec działań - a nie celów tych działań) i eternalizm etyczny. Jak pokazuje analiza tego rezonansu modyfikacja miała u Przełęckiego głównie charakter osłabienia odpowiednich idei.

Słowa kluczowe: antyirracjonalizm, eternalizm etyczny, indeterminizm, Marian Przełęcki, realizm praktyczny, reizm, rekonstrukcjonizm, Szkoła Lwowsko-Warszawska. 


\section{Summary}

\section{Resonance of the ideas of the Lvov-Warsaw School in the views of Marian Przełęcki}

In the article, I discuss the ideas that Marian Przelęcki shared with representatives of the Lvov-Warsaw School - either modifying them or giving better argumentation for them. These are, among others: (moderate) anti-irrationalism, stimulative rationalism (in relation to faith), logical (restrained) reconstructionism, (liberalized) conventionalism, ontological indeterminism (in the negative part), recognition of ontological reism as an explanatory hypothesis regarding semantic reism, the directive of practical realism (towards actions - and not towards the goals of these actions) and ethical eternalism. As the analysis of this resonance shows - Przełęcki's modification was mainly weakening relevant ideas.

Key words: anti-irrationalism, ethical eternalism, indeterminism, Lwow-Warsaw School, Marian Przełęcki, practical realism, reconstructionism, reism 